\title{
OBITUARY
}

\section{Professor Rehana Yaseen}

\section{September 1956 - 19 December 2020}

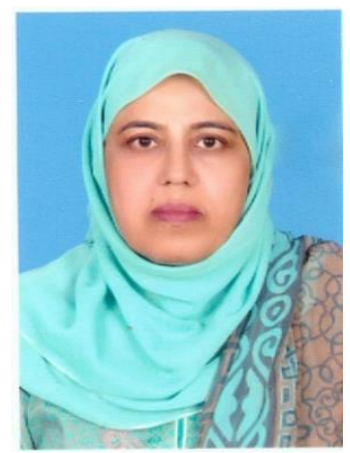

After a long and courageous battle against her disease Prof. Rehana Yaseen breathed her last on

December, 2020 at AKUH Karachi. She was diagnosed as suffering from leukemia about a year ago. Despite her disease and treatment she continued to work as Senior Cardiac Anesthetist till her death in PNS Shifa Karachi. She joined PNS Shifa in April, 2017 and helped establish Cardiac Surgery there.

Dr. Rehana was born on 3rd September 1956. She qualified MBBS from Sindh Medical College Karachi in 1980 and joined Department of Anesthesia \& Surgical ICU, Civil Hospital, Karachi in February 1983 as Medical Officer. She qualified MCPS (Anesthesiology) exam and in 1986 was promoted as Specialist Anesthetist.

In 1995 she qualified her FCPS exam and in September 1996 joined NICVD Karachi on deputation from government of Sindh. In 2001 she was inducted as assistant professor till February 2009, promoted as associate professor in August 2015. She took over as HoD Anesthesiology and ICU and was promoted as professor till her retirement in September 2016.

Dr. Rehana served as president, Pakistan Society of Anesthesiologists (PSA) Karachi and also president Pakistan Association of Cardiothoracic Anesthesiologists (PACTA) during 2009-2011, and she remained member Executive Committee of PSA Karachi and PACTA till her death.

She was examiner of CPSP and was keen in teaching and participating as invited speaker in courses for FCPS and MCPS trainees in different hospitals. She also played a pivotal part in starting Pediatric Cardiac ICU at NICVD.

Prof. Rehana was superb anesthesiologist, very kind, and immensely knowledgeable and she contributed a lot towards patient safety through her work.

She left behind her husband Mr. Muhammad Yaseen, two sons Haris and Bilal and four grandchildren. May Allah rest her soul in eternal peace. Ameen!

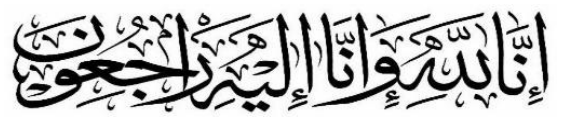

Prof. Amin M. Khuwaja

Head of the Department Anesthesia \& Intensive Care NICVD, Karachi, Pakistan. 